\title{
Quantification of Bioactive Molecules, Minerals and Bromatological Analysis in Carao (Cassia grandis)
}

\author{
Jhunior Abrahan Marcía Fuentes ${ }^{1,2}$, Ismael Montero Fernández ${ }^{3}$, Héctor Zumbado Fernández ${ }^{4}$, \\ Jesús Lozano Sánchez ${ }^{5}$, Ricardo Santos Alemán ${ }^{6}$, Miguel Navarro-Alarcon ${ }^{5}$, Isabel Borrás-Linares ${ }^{7}$ \\ $\&$ Selvin Antonio Saravia Maldonado ${ }^{8}$ \\ ${ }^{1}$ Faculty of Technological Sciences, Universidad Nacional de Agricultura, Catacamas, Olancho, Honduras \\ ${ }^{2}$ Faculty of Pharmacy and Food, University of Havana, Cuba \\ ${ }^{3}$ Department of Organic and Inorganic Chemistry, University of Extremadura, Cáceres, Spain \\ ${ }^{4}$ Faculty of Health Sciences, Universidad Técnica de Manabí, Ecuador \\ ${ }^{5}$ Department of Food Science and Nutrition, University of Granada, Granada, Spain \\ ${ }^{6}$ Department of Food Sciencie, Louisiana State University, USA \\ ${ }^{7}$ Functional Food Research and Development Centre, Granada, Spain \\ ${ }^{8}$ Faculty of Earth Sciences and Conservation, Universidad Nacional de Agricultura, Catacamas, Honduras \\ Correspondence: Jhunior Abrahan Marcia Fuentes, Faculty of Technological Sciences, Universidad Nacional de \\ Agricultura Road to Dulce Nombre de Culmí, Km 215, Barrio El Espino, Catacamas, Olancho, Honduras. E-mail: \\ juniorabrahamm@yahoo.com
}

Received: December 7, 2019

Accepted: January 8, 2020

Online Published: February 15, 2020

doi:10.5539/jas.v12n3p88

URL: https://doi.org/10.5539/jas.v12n3p88

\begin{abstract}
Medicinal plants have various beneficial conditions for humanity, one of them is its medicinal contribution due to the presence of phytochemicals and antioxidants, characterized by these bioactive compounds as the main source of nutraceuticals. The fruit of Cassia grandis, traditionally known as carao, is a plant that is attributed antimicrobial and medicinal properties. The objective of this work was to determine the bromatological, mineralogical composition and bioactive molecules of carao in the department of Choluteca (Honduras). Total phenolic compounds determined by the Folin-Ciocateau method resulted in higher concentrations in the seeds $11.1 \pm 0.3 \mathrm{mg}$ EAG $100 \mathrm{~g}^{-1}$. The antioxidant activity was also found to be higher in carao seeds, with concentrations of $7.31 \pm 0.11 \mu \mathrm{g} \mathrm{g}^{-1}$ of DPPH and total carotenoids showed higher concentration in the pulp with a concentration of $4.12 \pm 0.11 \mu \mathrm{g} \mathrm{mL}^{-1}$. Among the macro minerals, high concentrations of magnesium and calcium

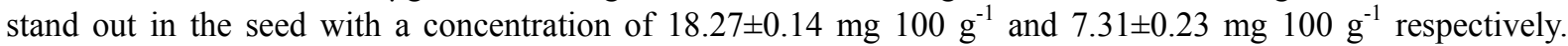
Among the microminerals, iron stands out in higher concentrations than in the rest of the microminerals being

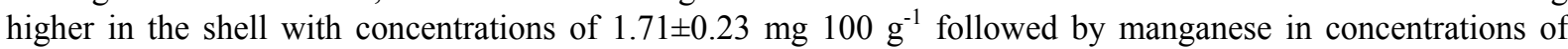
$0.51 \pm 0.12 \mathrm{mg} 100 \mathrm{~g}^{-1}$.
\end{abstract}

Keywords: iron, carotenoids, biotechnology, DPPH

\section{Introduction}

The carao, whose scientific name is Cassia grandis, belongs to the legume family and is a sub family of the Cesalpinaceae, it is commonly known by different names such as caña, fistula, cañandonga and carao (Lagarto \& Guerra, 2005; Carvalho, 2006; Lafourcade et al., 2014). There are approximately more than 500 Cassia species worldwide, represented as herbs, shrubs and trees (Sadiq et al., 2012; Korlam et al., 2016). This species is found in the wild mainly in India, China, East Africa, South Africa and in some countries of the American continent, such as Brazil, Colombia, Mexico, Cuba, El Salvador, Nicaragua, Costa Rica and Honduras (Lafourcade et al., 2014; Ramos et al., 2014; Marcía et al., 2017; Bomfim Gois et al., 2018). The carao fruits is rigid and can only be opened by applying mechanical forces, inside it many lobes are seen separated by very thin transverse partitions of yellowish color. A dark red flesh, thick consistency, strong odor, sweet taste and easily soluble in water (Jaime et al., 2012). 
The carao is a tree that grows from 15 to $30 \mathrm{~m}$ high, with a width of 45 to $100 \mathrm{~cm}$ with a cylindrical shaft that branches from the middle, round crown with about $8 \mathrm{~m}$ in diameter, its bark is smooth, of brown gray color, 30 $\mathrm{mm}$ thick, the leaves are composed and alternate with 15 to 20 pairs of opposite leaflets, 2 to $5 \mathrm{~cm}$ long and 1 to $1.5 \mathrm{~cm}$ wide, rounded base and green, the inflorescences have 15 or more flowers, an intense pink color, the seeds are 2 to $4 \mathrm{~cm}$ long and 1.5 to $2.5 \mathrm{~cm}$ wide and the pod that contains it can reach up to $75 \mathrm{~cm}$ in length (Figure 1) (Ramos et al., 2014).

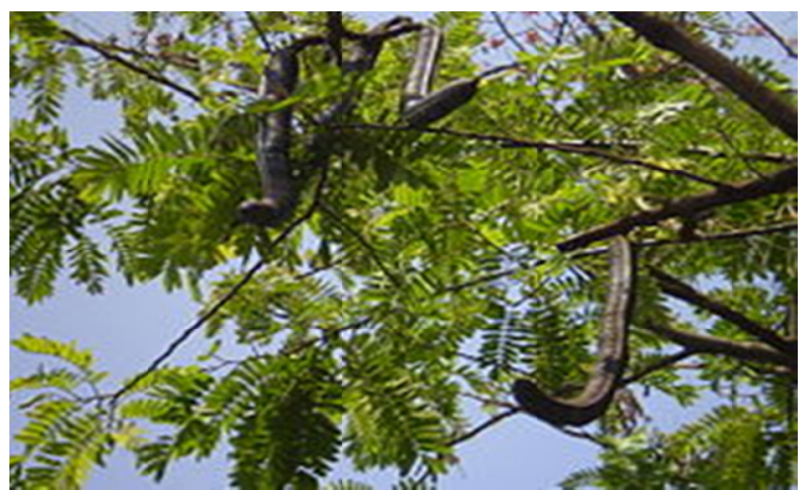

Figure 1. Carao (Cassia grandis)

Currently there are studies that validate the medicinal potential of Cassia grandis, due to its phytochemical composition, its antioxidant capacity and its high bioavailability. Romero et al. (2018) affirm that the seed of the fruit can be used as an anti-diabetic potential, due to its inhibitory effect of trypsin. Fruit pulp from in vivo models showed a reduction in blood glucose levels (Lafourcade et al., 2018; Lodha et al., 2019). Its nanodispersion exerts a hypoglycemic effect with a potent inhibition of alpha-glucosidase and pancreatic lipase (Lafourcade et al., 2019). In addition, the fruit of Cassia grandis has shown its anti-anemic potential from in vivo studies, due to its inorganic iron content and good bioavailability (Tillán et al., 2004; Lafourcade et al., 2014; Lafourcade et al., 2016). From studies of phytochemical characterization in carao fruit, it was determined that it contains good iron content, presence of saponins, porphyrins, flavonoids, tannins, phenols, essential oils and a high antioxidant capacity (Deshpande \& Bhalsing, 2011; Jaime et al., 2012; Ramos et al., 2014; Kabila et al., 2017).

Other investigations on carao extracts (Cassia grandis) determined the presence of the galactomannan biopolymer and, due to its rheological characteristics, can be used as a substitute for gums in the food industry (Harsha \& Kapoor, 2003). The objective of this work was to carry out a bromatological characterization of the different parts of the carao fruit, mineral analysis as well as composition of total phenolic compounds, antioxidant activity and carotenoids in the different parts of the fruit.

\section{Material and Methods}

\subsection{Sample Collection and Preparation}

The samples were collected in the department of Choluteca (Honduras) between February and March 2019, and were subsequently taken to the Biotechnology Laboratory of the National University of Agriculture, Catacamas (Honduras) where they were separated in different parts of the fruit and dried in an air circulation oven for 48 hours to maintain constant weight. Subsequently they were ground, sieved and stored in suitable containers until the time of the analysis.

\subsection{Bromatological Analysis}

The bromatological parameters analyzed to later determine the total energy value in the different parts of the fruit were the humidity, quantity of ashes carried out in a muffle at $600{ }^{\circ} \mathrm{C}$ and the percentage of ashes calculated by mass difference. Total proteins were determined by the Kjeldahl distillation method with previous sulfuric digestion. The percentage of total lipids was determined by Soxhlet type extractor with hexane and the percentage of carbohydrates was calculated by difference using Equation 1, according to the methodology described by IAL (2008).

$$
\text { Energetic value }\left(\mathrm{kcal} 100 \mathrm{~g}^{-1}\right)=\left(\mathrm{P}^{* 4}\right)+\left(\mathrm{L}^{* 9}\right)+\left(\mathrm{C}^{* 4}\right)
$$


Where, $\mathrm{P}=$ protein value $(\%), \mathrm{L}=$ lipid value $(\%), \mathrm{C}=$ carbohydrate value $(\%), 4=\mathrm{kcal}$ conversion factor determined in calorimetric pump for proteins and carbohydrates and $9=\mathrm{kcal}$ conversion factor determined in calorimetric pump for lipids.

\subsection{Mineral Analysis}

For the determination of minerals, the samples were first subjected to perchloric nitric digestion $(3: 1)$, the following elements being determined: $\mathrm{Ca}(\lambda=422.70 \mathrm{~nm}), \mathrm{Mg}(\lambda=285.21 \mathrm{~nm}), \mathrm{Fe}(\lambda=248.33 \mathrm{~nm}), \mathrm{Zn}(\lambda=$ $213.80 \mathrm{~nm}), \mathrm{Mn}(\lambda=279.48 \mathrm{~nm}), \mathrm{Cu}(\lambda=324.75 \mathrm{~nm})$ by FAAS, $\mathrm{Na}$ and $\mathrm{K}$ by EAS and by molecular spectrophotometry Uv-visible phosphorus $(\lambda=660 \mathrm{~nm})$ and sulfur $(\lambda=420 \mathrm{~nm})$ according to the methodology described by EMBRAPA (2008).

\subsection{Phenolic Compounds and Antioxidant Activity}

Total phenolic compounds was determined using the Folin Ciocateau method with formation of a blue complex using gallic acid as a reference standard, the absorbance readings being performed on a Uv-Visible spectrophotometer at $765 \mathrm{~nm}$ according with the methodology described by Wolfre et al. (2013). To determine the antioxidant activity, the method of the radical 1,1-diphenyl-2-picrilhydrazil (DDPH) was used and the iron reduction method was used. In the first method, the absorbance reading at $515 \mathrm{~nm}$ was performed (Miranda \& Fraga, 2006), the calibration being made from dilutions of a $60 \mathrm{mM}$ DPPH solution in methanol. The second method of determining the antioxidant activity was the method based on the reduction of $\mathrm{Fe}^{3+}$ for $\mathrm{Fe}^{2+}$ according to the methodology proposed by Sanchez Moreno et al. (2008), with the readings in Uv-Visible molecular absorption spectrophotometry a $690 \mathrm{~nm}$.

\subsection{Total Carotenoids}

For the quantification of total carotenoids, one g. of sample was extracted with $18 \mathrm{~mL}$ of acetone, the readings were made in UV-Visible molecular absorption spectrophotometer at $470 \mathrm{~nm}, 661 \mathrm{~nm}$ and $664 \mathrm{~nm}$ respectively, being calculated using Equations 2-4 described by Lichtenthaler and Buschmann (2001) (Equations 2-4),

$$
\begin{gathered}
\mathrm{C} \text { carotenoids }\left(\mathrm{mg} \mathrm{mL}^{-1}\right)=\left(1000 \mathrm{~A}_{470}-1.90 \mathrm{Ca}-63.14 \mathrm{Cb}\right) / 214 \\
\mathrm{Ca}\left(\mathrm{mg} \mathrm{mL}^{-1}\right)=11.24 \mathrm{~A}_{661}-2.04 \mathrm{~A}_{644} \\
\mathrm{Cb}\left(\mathrm{mg} \mathrm{mL}^{-1}\right)=20.13 \mathrm{~A}_{664}-4.19 \mathrm{~A}_{661}
\end{gathered}
$$

\subsection{Statistical Analysis}

The data was analyzed in the SPSS software, version 25.0, using, tukey test at $(\mathrm{P}<0.05)$ to identify significant differences.

\section{Results and Discussion}

\subsection{Bromatological Analysis}

In Table 1, the values of the nutritional composition and total energy value for the different parts of the fruit studied are presented.

Table 1. Bormatological composition and total energy value in carao

\begin{tabular}{lllllll}
\hline Fruit parts (\%) & Humidity & Ashes & Lipids & Carbohydrates & Proteins & Energetic Value $\left(\mathrm{Kcal}^{\left.100 \mathrm{~g}^{-1}\right)}\right.$ \\
\hline Pulps & $26.72 \mathrm{a}$ & $2.80 \mathrm{~b}$ & $0.21 \mathrm{~b}$ & $61.93 \mathrm{c}$ & $8.34 \mathrm{~b}$ & $\mathbf{2 8 2 . 9 7 c}$ \\
Shell & $8.19 \mathrm{c}$ & $2.42 \mathrm{c}$ & $0.14 \mathrm{c}$ & $88.01 \mathrm{a}$ & $1.24 \mathrm{c}$ & $\mathbf{3 5 8 . 2 6 a}$ \\
Seeds & $9.58 \mathrm{~b}$ & $3.74 \mathrm{a}$ & $1.17 \mathrm{a}$ & $75.40 \mathrm{~b}$ & $10.11 \mathrm{a}$ & $\mathbf{3 5 2 . 5 7 b}$ \\
Whole fruits & 17.31 & 3.14 & 0.74 & 71.4 & 7.41 & $\mathbf{3 2 1 . 9}$ \\
\hline
\end{tabular}

Note. * Means with different letters in the same column indicate statistical differences $(\mathrm{P} \leq 0.05)$ with Tukey test.

The highest humidity values for the different parts of the fruit studied are in the pulp, with values of $26.72 \%$ and the part that presented less moisture was the crust with only $8.19 \%$. The ash content in carao is one of the lowest bromatological parameters, with the seeds having the highest mineral value with $3.78 \%$. Among the parameters that contribute to the energy value of the fruit are lipids, carbohydrates and proteins, the amount of lipids is very low, reaching the value at $1.17 \%$ for the seeds. Again, the amount of protein is higher for seeds with $10.11 \%$. 
Carbohydrates, including fibers, are the major constituents of carao, with the peel presenting the highest percentage of carbohydrates with $88.01 \%$.

Among the parameters that contribute to the energy value of the fruit are lipids, carbohydrates and proteins. The amount of lipids is very low, reaching the value at $1.17 \%$ for the seeds. Again, the amount of protein is higher for seeds with $10.11 \%$. Carbohydrates, including fibers, are the major constituents of carao, with the peel presenting the highest percentage of carbohydrates with $88.01 \%$. Given the high percentage of carbohydrates found in legumes, and especially in carao, they can be used as an unconventional food source. The carbohydrate content in this legume is higher than that found in other tropical legumes such as Inga, whose percentage reaches $27.62 \%$ (Mendoza et al., 2016). As for the energy value, the part of the fruit that has an important contribution is the shell with $358.26 \mathrm{kcal} 100 \mathrm{~g}^{-1}$. The daily energy recommendations of legumes are around 2,000 kcal $100 \mathrm{~g} \mathrm{~g}^{-1}$ in accordance with the specifications of the European Economic Community 90/496/EEC of September 24, 1990.

\subsection{Mineralogical Analysis}

Table 2 shows the values of the different minerals analyzed for the different parts of the fruit studied, as well as for the whole fruit of carao. Among the macro minerals, magnesium stands out as the majority, being its highest

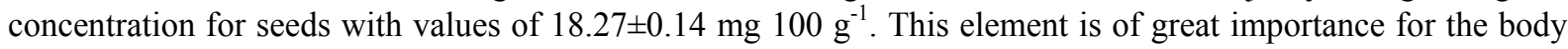
as it is involved in numerous metabolic reactions (Wolfe \& Cittadini, 2003). The recommendations of this element according to DRI (2011) are $420 \mathrm{mg} \mathrm{day}^{-1}$ for men and $320 \mathrm{mg} \mathrm{day}^{-1}$ for women. The next element in importance within the macro minerals is calcium which, like magnesium, this element is in higher concentrations

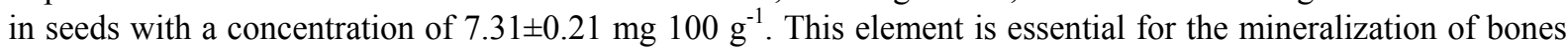
and teeth (França \& Martini, 2014) being the recommendations of $1000 \mathrm{mg}$ day $^{-1}$ for both sexes, according to the recommendations of the DRI (2011). Sodium and potassium are also two important elements to maintain the electrolyte balance in the cell such as the sodium potassium pump (Cuppari \& Bazanelli, 2010). In carao fruit,

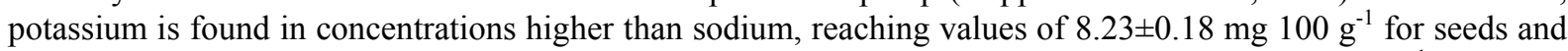
instead sodium is found in higher concentrations in the pulp, in concentrations of $2.56 \pm 0.13100 \mathrm{mg} \mathrm{g}^{-1}$.

Table 2. Shows the macro and micromineral values in the different parts of the carao, as well as in the whole fruit

\begin{tabular}{lllll}
\hline Concentration $\left({\left.\mathrm{mg} 100 \mathrm{~g}^{-1}\right)}^{-1}\right.$ & Seeds & Pulps & Shells & Whole fruits \\
\hline $\mathrm{Ca}$ & $7.31 \pm 0.21 \mathrm{a}$ & $5.67 \pm 0.12 \mathrm{~b}$ & $4.67 \pm 0.17 \mathrm{c}$ & $6.21 \pm 0.12$ \\
$\mathrm{Mg}$ & $18.27 \pm 0.14 \mathrm{a}$ & $14.31 \pm 0.12 \mathrm{~b}$ & $11.21 \pm 0.07 \mathrm{c}$ & $15.46 \pm 0.07$ \\
$\mathrm{~K}$ & $8.23 \pm 0.18 \mathrm{a}$ & $3.45 \pm 0.07 \mathrm{~b}$ & $2.43 \pm 0.14 \mathrm{c}$ & $4.31 \pm 0.08$ \\
$\mathrm{Na}$ & $0.85 \pm 0.07 \mathrm{c}$ & $2.56 \pm 0.13 \mathrm{a}$ & $1.31 \pm 0.07 \mathrm{~b}$ & $1.47 \pm 0.31$ \\
$\mathrm{Fe}$ & $1.71 \pm 0.23 \mathrm{a}$ & $1.54 \pm 0.12 \mathrm{~b}$ & $0.81 \pm 0.07 \mathrm{c}$ & $1.14 \pm 0.21$ \\
$\mathrm{Cu}$ & $0.21 \pm 0.08 \mathrm{~b}$ & $0.14 \pm 0.03 \mathrm{c}$ & $0.71 \pm 0.12 \mathrm{a}$ & $0.44 \pm 0.11$ \\
$\mathrm{Zn}$ & $0.46 \pm 0.09 \mathrm{a}$ & $0.34 \pm 0.11 \mathrm{~b}$ & $0.21 \pm 0.07 \mathrm{c}$ & $0.27 \pm 0.13$ \\
$\mathrm{Mn}$ & $0.51 \pm 0.12 \mathrm{a}$ & $0.25 \pm 0.07 \mathrm{~b}$ & $0.21 \pm 0.07 \mathrm{c}$ & $0.38 \pm 0.08$ \\
$\mathrm{P}$ & $0.47 \pm 0.07 \mathrm{a}$ & $0.21 \pm 0.02 \mathrm{~b}$ & $0.14 \pm 0.07 \mathrm{c}$ & $0.26 \pm 0.08$ \\
$\mathrm{~S}$ & $0.08 \pm 0.01 \mathrm{c}$ & $0.17 \pm 0.04 \mathrm{a}$ & $0.11 \pm 0.03 \mathrm{~b}$ & $0.04 \pm 0.01$ \\
\hline
\end{tabular}

Note. * Means with different letters in the same line indicate statistical differences $(\mathrm{P} \leq 0.05)$ with Tukey test.

The daily recommendations for this element in adulthood are $8 \mathrm{mg} \mathrm{day}^{-1}$ for men and for women aged 19-50 years. The recommended concentrations are $18 \mathrm{mg}$ day $^{-1}$ and from 50 years of $8 \mathrm{mg} \mathrm{day}^{-1}$ according to the DRI (2011). Manganese is another of the micronutrients found in carao in significant concentrations, the highest

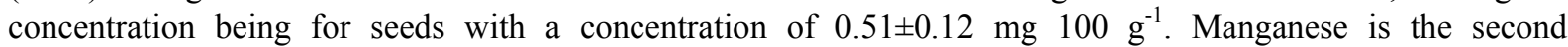
micronutrient after iron of interest to plants (Malavolta, 2006), but at the same time it plays an antagonistic role with iron in the body, since in the diet, excess manganese can cause reduced absorption of iron causing anemia in addition to affecting the central nervous system (Roels et al., 1997). Zinc has different physiological functions in the cell, such as the hepatic mobilization of vitamin A, in sexual maturation, fertility and reproduction, phagocytic, cellular and humoral immune function (Manganaro, 2008) the concentration in carao seeds being $0.46 \pm 0.09 \mathrm{mg} 100 \mathrm{~g} \mathrm{~g}^{-1}$. Copper is another essential nutrient not synthesized by the body, being found in fruits in concentrations between 0.02-0.66 mg $100 \mathrm{~g}^{-1}$ according to Amancio (2017). 
In carao, the copper concentrations found are very low, being in greater concentration in the bark of this fruit in a concentration of $0.71 \pm 0.12 \mathrm{mg} 100 \mathrm{~g}^{-1}$. Two other elements analyzed in this fruit were phosphorus and sulfur. The highest phosphorus concentration was found in the seed with a concentration of $0.47 \pm 0.07 \mathrm{mg} \mathrm{g}^{-1} \mathrm{~g}^{-1}$ acting in the energy metabolism of ATP, involved in carbohydrate metabolism and present at the same time in the synthesis of phosphated sugars, nucleic acids and coenzymes (Epstein \& Bloom, 2006). Sulfur was found in low

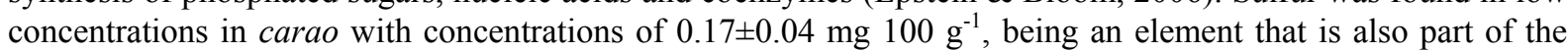
structure of biomolecules such as proteins and found in the body in concentrations of up to 140 grams (Lisbon, 2015).

\subsection{Phenolic Compounds, Antioxidant Activity and Total Carotenoids}

Table 3 shows the values of phenolic compounds, antioxidant activity and total carotenoids in the different parts of the carao fruits.

Table 3. Phenolic compounds, antioxidant activity and total carotenoids in different parts of carao

\begin{tabular}{|c|c|c|c|c|}
\hline \multirow{2}{*}{ Parts } & \multirow{2}{*}{$\begin{array}{l}\text { Total Phenolic Compounds } \\
\left(\mathrm{mg} \mathrm{EAG} 100 \mathrm{~g}^{-1}\right)\end{array}$} & \multicolumn{2}{|c|}{ Antioxidant Activity } & \multirow{2}{*}{$\begin{array}{l}\text { Total carotenoids } \\
\left(\mu \mathrm{g} \mathrm{mL} L^{-1}\right)\end{array}$} \\
\hline & & DPPH $\left(\mu \mathrm{g} \mathrm{g}^{-1}\right)$ & Iron reduction $\left(\mathrm{mg} \mathrm{g}^{-1}\right)$ & \\
\hline Pulp & $5.6 \pm 0.2 b$ & $6.07 \pm 0.02 b$ & $0.21 \pm 0.01 \mathrm{~b}$ & $4.12 \pm 0.11 \mathrm{a}$ \\
\hline Shells & $2.3 \pm 0.1 \mathrm{c}$ & $5.12 \pm 0.04 \mathrm{c}$ & $0.18 \pm 0.02 \mathrm{c}$ & $2.21 \pm 0.07 \mathrm{c}$ \\
\hline Seeds & $11.1 \pm 0.3 \mathrm{a}$ & $7.31 \pm 0.11 \mathrm{a}$ & $0.41 \pm 0.02 \mathrm{a}$ & $3.76 \pm 0.03 \mathrm{~b}$ \\
\hline Fuit total & $6.3 \pm 0.1$ & $6.48 \pm 0.07$ & $0.34 \pm 0.04$ & $2.56 \pm 0.04$ \\
\hline
\end{tabular}

Note. * Means with different letters in the same column indicate statistical differences $(\mathrm{P} \leq 0.05)$ with Tukey test.

The total phenolic compounds determined in the different parts of the carao samples as well as in the whole fruit varied between $2.3 \pm 0.1 \mathrm{mg}$ EAG $100 \mathrm{~g}^{-1}$ for the shell to concentrations of $11.1 \pm 0.3 \mathrm{mg}$ EAG $100 \mathrm{~g}^{-1}$ for the seeds, this part being the one with the highest concentration of phenolic compounds. In comparison with other legumes such as Vicia faba, these values are within those determined by Valente et al. (2018), reaching values of $13 \pm 0.1 \mathrm{mg}$ EAG $100 \mathrm{~g}^{-1}$. The antioxidant activity, was carried out by two methods: by means of the DPPH technique and on the other hand by means of the iron reduction method, being again the carao seed who has the highest antioxidant activity with antioxidant activity values of $7.31 \pm 0.11 \mu \mathrm{g} \mathrm{g}^{-1}$ by the DPPH method and $0.34 \pm 0.04 \mathrm{mg} \mathrm{g}^{-1}$ by the iron reduction method. Godevac et al. (2008) study the antioxidant activity of nine species of Fabaceae, obtaining values higher than those obtained for carao. Other authors such as Pirela et al. (2011), study the antioxidant activity in the Genisteae also belonging to the Fabaceae family, obtaining values of 0.15 to $0.50 \mathrm{mg} \mathrm{mL}^{-1}$, being lower than those determined in this work. The last group of molecules studied in this work are the carotenoids that give the compound a certain added biotechnological potential, since they are precursors of vitamin A, they have antioxidant, anti-inflammatory and anti-tumor properties (Rehman, 2020). The concentrations of this group of substances in the study species varied between $2.21 \pm 0.07 \mu \mathrm{g} \mathrm{mL}^{-1}$ for the cortex of the carao, reaching values of $4.12 \pm 0.11 \mu \mathrm{g} \mathrm{mL}^{-1}$ for the pulp, being in this part of the fruit where the highest amount of carotenoids is found.

\section{Conclusions}

Although carao has been traditionally used in countries of Central America as a nutritional alternative, specifically to meet the needs of iron in blood, there is not much data regarding its chemical composition, so this work serves to highlight the energy, mineralogical and Bioactive molecules that this fruit has to be used with biotechnological potential in neutraceutical foods.

\section{Acknowledgements}

To Dr. Domingo Barrera, CICODE, Grupo Coimbra, Erasmus Mundus, CIDAF and the University of Granada-Spain, for their support in the development of this research.

\section{References}

Amancio, O. M. S. (2017). Funções Plenamente reconhecidas de nutrientes cobre. São Paulo: Série de Publicações ILSI Brasil.

Bomfim, G. I., Ferreira, R. A., \& Silva-Mann, R. (2018). Genetic Variability in Natural Populations of Cassia grandis L. F. Floresta e Ambiente, 25, e20160309. https://doi.org/10.1590/2179-8087.160309 
Carvalho, P. E. R. (2006). Cássia Rósea y Cassia grandis (Circular Técnica 117, pp. 1-8). Colombo: Embrapa Florestas.

Cuppari, L., \& Bazanelli, A. P. (2010). Funções Plenamente reconhecidas de nutrientes Potássio. São Paulo: Série de Publicações ILSI Brasil.

Da Silva, F. C. (2009). Manual de análises químicas de solos, plantas e fertilizantes.Brasilia. Embrapa: Brasilia.

De França, N. A., \& Martini, L. A. (2014). Funções Plenamente reconhecidas de nutrientes Cálcio. São Paulo: Série de Publicações ILSI Brasil.

Fisberg, M. (2014). Funções Plenamente reconhecidas de nutrientes Ferro. São Paulo: Série de Publicações ILSI Brasil.

Godevac, D., Zdunic, G., Sabikin, K., Vajs, V., \& Menkovié, N. (2008). Antioxidant activity of nine Fabaceae species growing in Serbia and Montenegro. Fitoterapia, 79, 185-187. https://doi.org/10.1016/j.fitote.2007. 10.001

Harsha, J., \& Kapoor, V. P. (2003). Cassia grandis Linn. seed galactomannan: Structural and crystallographical studies. Carbohydrate Research, 338, 1907-1912. https://doi.org/10.1016/s0008-6215(03)00258-1

Instituto Adolfo Lutz. (2008). Métodos físico-químicos para análise de alimentos (4th ed.). São Paulo, Brazil.

Jaime, M. J. A., Pitty, T. J., \& Gutiérrez, A. M. (2012). Determinación del hierro total en el fruto de Cassia grandis L. por espectrometría ultravioleta visible (p. 44, Tesis de grado, Licenciatura en Química, Laboratorio de Cromatografía, Departamento de Química, Universidad Nacional Autónoma de Nicaragua, León, Nicaragua).

Kabila, B., Sidhu, M. C., \& Ahluwalia, A. S. (2017). Phytochemical Profiling of Different Cassia species (Review). International Journal of Pharmaceutical \& Biological Archives, 8, 12-20.

Korlam, S., Papani, S., Mylisetti, V. P., \& Chitoor, M. S. (2016). Preliminary phytochemical screeningof fruits of Cassia spectabilis D.C. Journal of Biomedical and Pharmaceutical Research, 5, 41-44.

Lafourcade, P. A., Bitencourt, A., Rodríguez, A. J. R., Cruz, A. S. R., Tavares, C. J. C., \& Pinho, F. C. (2016). Development and characterization of Cassia grandis and Bixa orellana nanoformulations. Curr. Top. Med. Chem., 16, 1-9. https://doi.org/10.2174/1568026616666160215161103

Lafourcade, P. A., Rodríguez, A. J., Keita, H., Zapata, E., Carvalho, H., Silva, L, E., ... Tavares, C. J. (2018). Cassia grandis fruit extract reduces the blood glucose level in alloxaninduced diabetic rats. Biomedicine \& Pharmacotherapy, 103, 421-428. https://doi.org/10.1016/j.biopha.2018.04.059

Lafourcade, P. A., Rodríguez, A. J., Escalona, A. J., \& Fuenzalida, C. (2014). Estado del arte sobre Cassia grandis L. (Cañandonga). Revista Cubana de Plantas Medicinales, 19, 21-28.

Lagarto, P. A., \& Guerra, S. M. (2005). Toxicidad aguda oral a partir de 3 formas farmacéuticas de Cassia grandis L. Revista Cubana de Plantas Medicinales, 5, 68-70.

Lichtenthaler, H. K., \& Buschmann, C. (2001). Chloriphylls and carotenoids: Measurement and characterization by UV-VIS Spectroscopy. Current Protocols in Food Analytical Chemistry, F4.3-F4.8. https://doi.org/ 10.1002/0471142913.faf0403s01

Lisboa, W. (2015). Ciclo do Enxofre-Bacterias Sulfitogenica. Retrieved from https://prezi.com/whnr68fmklir/ ciclo-do-enxofre-bacterias-sulfitogenica

Lodha, S. R., Joshi, S. V., Vyas, B. A., Upadhye, M. C., Kirve, M. S., \& Salunke, S. S. (2010). Assessment of the antidiabetic potential of Cassia grandis using an in vivo model. J. Adv. Pharm. Tech. Res., 1, 330-333. https://doi.org/10.4103/0110-5558.72429

Malavolta, E. (2006). Manual de nutrição mineral de plantas. São Paulo: Editora Agronômica Ceres.

Manganaro, M. M. (2008). Nutrição aplicada à enfermagem. In G. F. Murta (Ed.), Saberes e práticas: Guia para ensino e aprendizado de enfermagem (Vol. 3). São Caetano do Sul, Brazil.

Mendoza, N. A. S., Martínez, C. J., Martínez, A. C., Barba, S. M. C., \& Ortiz, G. D. (2016). Physical, nutritional and non nutritional characterization of Inga paterno seeds. Revista Chilena Nutricion, 43, 400-407. https://doi.org/10.4067/S0717-75182016000400010 
Miranda, A. L. P., \& Fraga, C. A. M. (2006). Atividade Seqüestradora de Radical Livre Determinação do Potencial Antioxidante de Substâncias Bioativas. In A. Monge \& C. R. Ganellin (Eds.), Pratical Studies for Medicinal Chemistry. Genebra: IUPAC.

Normativa Comunidad Económica Europea 90/496/CEE de 24 de Septiembre de 1990. Retrieved from https://eur-lex.europa.eu/legal-content/ES/TXT/?uri=CELEX\%3A31990L0496

Pinela, J., Barros, L., Carvalho, A. M., \& Ferreira, I. C. F. R. (2011). Influence of the drying method in the antioxidant potential and chemical composition of four shrubby flowering plants from the tribe Genisteae (Fabaceae). Food and Chemical Toxicology, 49, 2983-2989. https://doi.org/10.1016/j.fct.2011.07.054

Ramos, E., Paz, J., Ortiz, G., \& Nuñez, K. (2014). Determinación del contenido de hierro, saponinas y porfirinas en Cassia grandis L., procedente de Masaya, Chinandega y Jalapa (p. 46, Tesis de grado, Químico Farmacéutico, Universidad Nacional Autónoma de Nicaragua, León, Nicaragua).

Rehman, A., Tong, Q., Jafari, S. M., Assadpour, E, Shehzad, Q., Aadil, R. M., ... Asharf, W. (2020). Carotenoid-loaded nanocarriers: A comprehensive review. Advances in Colloid and Interface Science, 275, 102048. https://doi.org/10.1016/j.cis.2019.102048

Roels, H. M. G., Meires, M., Delos, I., Ortega, R., Lauwerys, J. P., \& Buschet, D. L. (1997). Influence of the route o administration and the chemical form $\left(\mathrm{MnCl}_{2}, \mathrm{MnO}_{2}\right)$ on the absorption and cerebral distribution of manganese in rats. Archives of Toxicology, 71, 223-230. https://doi.org/10.1007/s002040050380

Romero, M. P., Costa, B., Ferreira, V., \& Porto, A. L. (2018). CgTI, a novel thermostable Kunitz trypsin inhibitor purified from Cassia grandis seeds: Purification, characterization and termiticidal activity. International Journal of Biological Macromolecules, 118, 2296-2306. https://doi.org/10.1016/j.ijbiomac.2018.07.110

Sadiq, I. S., Shuaibu, M., Bello, A. B., \& Tureta, S. G., Isah, A., \& Izuagie, T. (2012). Phytochemistry and antimicrobial activities of Cassia occidentalis used for herbal remedies. Journal of Chemical Engineering, 1, $38-41$.

Sanchez-Moreno, C., Larrauri, J. A., \& Saura-Calixto, F. (1998). A procedure to the antiradical efficiency of polyphenolds. Journal of the Science of Food and Agriculture, 76, 270-276. https://doi.org/10.1002/(SICI) 1097-0010(199802)76:2<270::AID-JSFA945>3.0.CO;2-9

Tillán, C. J., Rodríguez C. J., Gómez, M. J. M., Pardo, R. Z., \& Agüero, F. S. (2004). Actividad antianémica de la Cassia grandis L. Revista Cubana de Farmacia, 38(1).

Valente, I. M., Maia, M. R. G., Malushi, N., Oliveira, H. M., Papa, L., Rodrigues, J. A., ... Cabrita, A. R. J. (2018). Profiling of phenolic compounds and antioxidant properties of European varieties and cultivars of Vicia faba L. pods. Phytochemistry, 152, 223-229. https://doi.org/10.1016/j.phytochem.2018.05.011

Wolf, F. I., \& Cittadini, A. (2003). Chemistry and biochemistry of magnesium. Molecular Aspects of Medicine, 24, 11-26. https://doi.org/10.1016/s0098-2997(02)00087-0

Wolfe, K., Wu, X., \& Liu, R. H. (2003). Antioxidant activity of apple peels. J. Agric. Food Chem., 51, 609-614. https://doi.org/10.1021/jf020782a

\section{Copyrights}

Copyright for this article is retained by the author(s), with first publication rights granted to the journal.

This is an open-access article distributed under the terms and conditions of the Creative Commons Attribution license (http://creativecommons.org/licenses/by/4.0/). 